
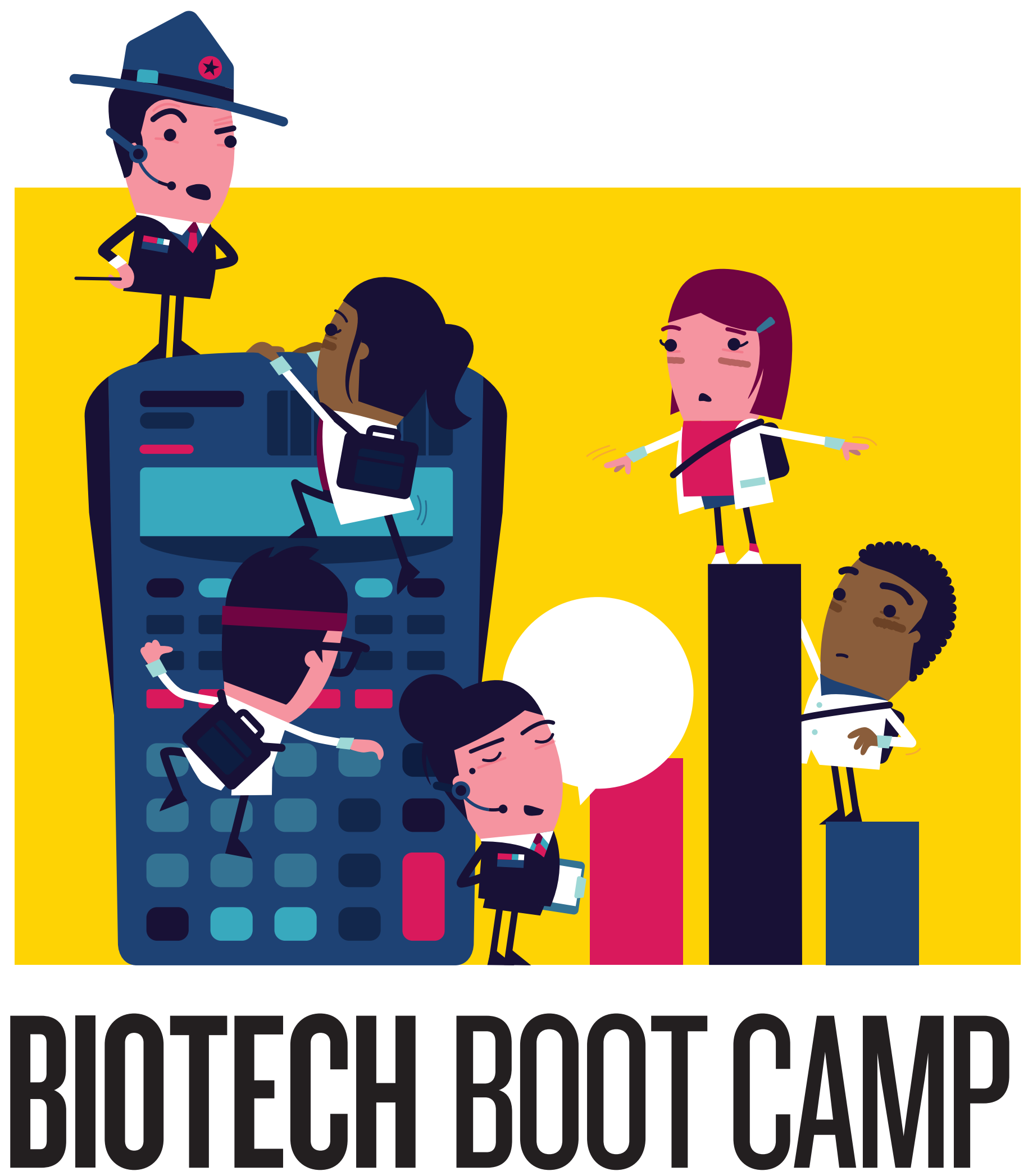

US funding agencies are turning to a Silicon Valley entrepreneur to focus fledgling biomedical companies on success - even when that means making a scientific course correction.

BY HEIDI LEDFORD

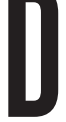

avid Johnson was just one minute into making his pitch when the interruptions started.

"Why do I care?" barked a bespectacled man at the back of the seminar hall. Johnson, chief executive of the California biotechnology start-up GigaGen, blinked. He had condensed his company's story into a neat ten-minute presentation for I-Corps, a nine-week course designed to teach business skills to entrepreneurial scientists like him. Now his talk was derailed. 
At first Johnson did not understand the question. He thought it was aimed at the therapy that GigaGen, based in San Francisco, plans to develop for people with weakened immune systems.

"No. You. Why do I care about you?" the man demanded.

Johnson was not the only one getting gruff treatment at I-Corps' kickoff meeting in Chevy Chase, Maryland, last October. When another team squandered a few precious minutes elaborating on the need for new therapies to treat pain, I-Corps creator Steve Blank pounced. "If you spend the next ten weeks telling us about pain, you're going to be in pain," he said.

Blank later let fly again. "You may have noticed that your presentation was different from the others - and not in a good way," he told the president of another firm who had not clearly elaborated his team's business strategy.

Rough treatment like this is part of the pedagogy of I-Corps, a boot camp for technology-based start-ups that has now been rolled out for biomedical firms as part of an experiment by the US National Institutes of Health (NIH). Blank had given his fellow teachers explicit instructions to rattle the teams to make them more receptive to change. "The shock-and-awe part is not to embarrass people or make them feel bad," he says, "but to get them out of their default mode of 'I think it, therefore it must be right"'

It will take years to find out whether the approach and theory behind I-Corps is adaptable to the unique challenges of drug development. But it was already clear by the conclusion of the inaugural class last December that many of the 19 teams had learned some unexpected lessons: several companies were told to drastically change course, and in some cases to abandon promising science for something more marketsavvy. "You can be a great researcher and you can think you have great ideas," says Congressman Dan Lipinski (Democrat, Illinois), who had pushed to see Blank's approach implemented for government-funded research. "But until you're forced to talk to a potential customer, you never really know."

\section{ALL ABOUT THE SCIENCE}

At 61, Blank epitomizes the contradictions of California's Silicon Valley, with a sun-drenched conviviality that never completely conceals his no-nonsense efficiency. He will take the time to tell a funny anecdote - often using himself and his business mistakes as the punchline - but almost every session of the I-Corps meetings in Chevy Chase adjourned ahead of schedule.

Blank is a college drop-out who wandered into Silicon Valley in 1978 after years of repairing fighter jets for the US Air Force. He arrived in California just before the technology boom, and his love of gadgets made him a perfect fit. He was involved in eight technology companies there, not all of them successful; he counts two "craters" among them. Then, in 1999, he retired to a ranch in Pescadero, California. The sudden infusion of free time allowed him to examine his successes - and, more importantly, his failures.

From that introspection he crafted a curriculum for tech entrepreneurs, to teach them to think beyond their own technology and to dive early and deep into the details of commercialization: who the customers are, what they need and how much they are willing to pay. The technique has swept through the tech industry, says Steven Phelan, who studies entrepreneurship at Fayetteville State University in North Carolina. It is bringing welcome changes to the way that businesses are developed, but some find flaws in the approach. Relying too heavily on customer input can lend itself to incremental - rather than revolutionary - improvements, Phelan cautions. "If you ask people what they want, they're just going to say something that they're familiar with," he says. (Blank counters that customer research can be tailored to avoid this problem.)

A few years ago, Lipinski, a former engineer who serves on the US House Committee on Science, Space, and Technology, dropped in on a class Blank taught at Stanford University, and saw a new use for the programme. "This is something researchers don't have training in," he says. "I was sold."
Lipinski has long been concerned about the quality of research funded by the US Small Business Innovation Research (SBIR) programme. The funds are intended to stimulate translation of scientific discoveries into the marketplace, but critics have raised questions about how effective the programme is. A 2013 analysis by Nature found that the top earners of such grants were rarely focused on commercialization (see Nature 499, 137-138; 2013). "Sometimes it seems like SBIR is being used in many cases not to further a business, but to continue research," says Lipinski.

In Blank's class, Lipinski saw a way to beef up the business acumen of SBIR grant recipients. He urged the NIH and the National Science Foundation (NSF) to adopt the programme. The NSF picked it up first, christened it I-Corps, for Innovation Corps, and offered it to scientists

\section{"UNTIL YOU'REFORCEDTOTALK TOAPOTENTIALCUSTOMER, YOU NEVER REALLYKNOW."}

on the threshold of launching a company. Since 2011, about 500 teams have taken the course. If success can be measured by personal epiphanies, then it has been a qualified victory: almost every team changed its original business strategy, and more than half of them went on to found a company.

It took until last year for the NIH to sign on, with the National Cancer Institute (NCI) serving as guinea pig. In the beginning, Blank had said that his method was applicable to all industries - except one. "I said it wouldn't work for life sciences because it takes 10 to 15 years to get to a phase I clinical trial," he says. "There, it really was all about the science."

But in 2013, the head of technology transfer at the University of California, San Francisco, convinced Blank to challenge those assumptions. Blank did what he tells his own students to do: he went out into the community to interview leaders in the biomedical industry.

Those leaders told him that his conception of the pharmaceutical business was outdated. Blank was imagining the drug development of the 1990s, when in-house scientists carried out much of the research at big companies, and large firms forged few partnerships with smaller players. In that model, a small biotechnology firm had no customers until it had nearly brought its drug to market.

Since then, the pharmaceutical industry has changed. Companies have cut back on in-house research in favour of early partnerships with smaller firms - effectively turning big pharma into early customers. Blank realized that the I-Corps approach might help biomedical researchers hoping to enter this world. But he recognized important differences between biology-based start-ups and the tech firms where he had cut his teeth.

First, biomedical firms are much more heavily regulated, even before their product hits the market. Second, intellectual property is more important for health-care companies - the patents that a company can file and license wield enormous influence over the direction of its business. The third, and perhaps most overlooked, challenge: payment for services and therapies in the United States is often indirect and complex, involving a labyrinthine system of billing codes and intermediaries. Understanding those particulars - how procedures and therapies are billed, how insurance companies process the claims - is not sexy science, but it is crucial. "Grandma is not the one paying for her new hip," says Blank. "If you don’t understand reimbursement, you're dead."

\section{THE INTERVIEW}

Blank worked hard to get that message across during the three-day kick-off meeting in October as the teaching staff grilled the teams. Each morning was spent presenting - and then re-presenting - the ten-minute team pitches. Each afternoon, the teams raced to interview 


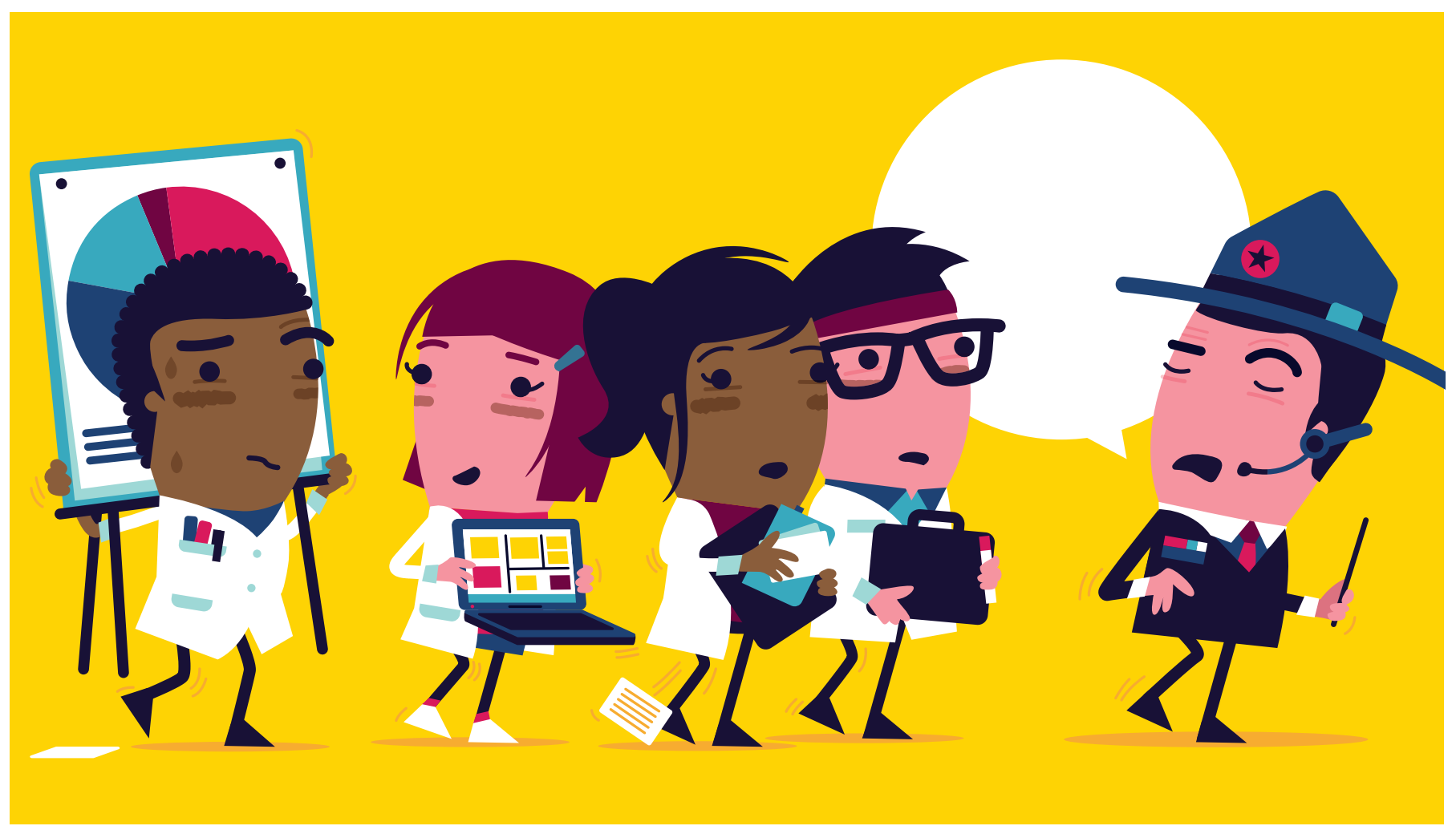

experts in their fields, then reported back for more workshops. Nights were filled with class readings, homework and preparations for the next day's presentations and interviews.

The interviews are central to the process (see 'Start-up pitfalls'). Teams needed to talk to scientists, pharma company reps, regulators, doctors, billing specialists and more - essentially, any person with expertise in what it takes for companies to get their products to patients and get paid. It is a time-consuming process, and Blank insists that the interviews be conducted face-to-face, to build rapport and allow interviewers to better gauge their subjects' emotions. If an expert cannot be met in person, the

\section{"JUST THAT ONECHANGE MIGHT BEWORTH \$5OMILLION."}

team must hold a video-conference. When one team let slip that some of its interviews were done over the phone, Blank's face grew red. "This is bullshit," he spat, and invited the team to leave the programme. (It stayed.)

Other teams embraced the I-Corps strategy with gusto. One morning, Eric Bressler, a research scientist at AsclepiX Pharmaceuticals in Baltimore, Maryland, told the group how his team had shown up at a hospital and bounced from one administrative assistant to another, asking questions about how treatments are billed and reimbursed. Eventually someone noticed that the team did not have clearance from security to wander around asking questions. It was escorted out. "I predict great things," said Blank, admiring the team's audacity. "And/or an arrest record." (His praise proved ephemeral, however: a few minutes later he scolded Bressler for wasting time with the story: "You were bullshitting for a large part of your presentation.")

Some said that the interviews provided immediate insight. BCN Biosciences of Pasadena, California, had been in business for nearly a decade developing drugs to protect normal tissue from radiation during cancer treatments. One of the first things the team learned is that because new technologies can deliver radiation more precisely, doctors saw no great need to protect healthy tissue. It was an 'Aha' moment, says Andrew Norris, BCN's director of research. "Trying to sell something that nobody wants is a stupid thing to do."

Of all the learning that happened during those first few days in Chevy Chase, Blank seemed most proud of the progress of Abreos Biosciences, a company in San Diego, California, that is developing ways to detect counterfeit drugs. The team's presentation, 'Lateral flow immunoassay for therapeutic monoclonal antibody quality assurance', was ridiculed by one instructor. "Could you make it more complicated?" he ribbed.

By day three, the team had swapped technical terms for more marketfriendly lingo. The title became, 'Quick tests for point-of-care validation of biologic drugs'. Abreos co-founder Bradley Messmer also developed better ways to describe their product, likening it to "a pregnancy test that tells you whether your drug is real or not".

Blank was thrilled that the team had learned how to talk to investors better. "For commercialization, being able to explain it to your mother is what matters," he said. "Just that one change might be worth $\$ 50$ million."

\section{PIVOT POINTS}

When the kick-off meeting ended, the teams returned home to complete their coursework: more interviews, at least 100 over the next 9 weeks. Several I-Corps participants were already weighing up significant changes to their business strategy.

AsclepiX, which was founded by bioengineers at Johns Hopkins University in Baltimore, Maryland, had been developing a cancer therapy based on the marriage of two unusual approaches - a novel drug made of a short string of amino acids, and a nanoparticle to target the drug to cancer cells. The company had exciting preclinical data on head and neck tumours and was eager to move the drug forward.

But early interviewees advised the team to change focus. Head and neck cancers are too heterogeneous, they said, and there are already a

\section{$\rightarrow$ NATURE.COM}

For an interview with the author visit: go.nature.com/ezklgh number of available therapies to treat them. AsclepiX's drug targets blood vessels that feed tumours, and similar drugs had shown promise against glioblastoma, a rare and devastating brain tumour with few available treatments. 


\section{START-UP PITFALLS \\ I-Corps instructors push students to avoid these mistakes commonly made by fledgling companies}

1. DON'T FALL IN LOVE. I-Corps professes a 'fail fast' model. Rather than getting married to ideas, test them and be ready to discard them.

2. DON'T SPEND ALL YOUR TIME AT THE BENCH. Businesses need to interview key decision-makers for every stage of their product's life cycle. I-Corps mandates a minimum of 100 interviews to understand the market and the customer.

3. DON'T MAKE THE INTERVIEW A SALES PITCH. Trying to sell a company's idea at an informational interview will backfire. It will bias the conversation and make it less valuable.

4. DON'T FORGET WHO PAYS. For biomedical businesses, reimbursement is complicated and varies widely depending on the product and the medical condition it is designed to treat. Failing to appreciate this is disastrous.

5. DON'T CHASE THE WRONG DATA. What it takes to elicit a partnership with a pharma company is not always what it takes to get a paper accepted. (Companies often want to see reproducibility in different labs or with different source material.)

Some interviewees suggested that a treatment for glioblastoma would be eligible for accelerated approval programmes in the United States and Europe, clinical trials would be smaller, and there would be less competition from other therapies. The AsclepiX crew began to get up to speed on glioblastoma, and planned interviews with neuro-oncologists.

It soon identified another problem: the nanoparticle. This would provide better targeting and protect the drug in the bloodstream, but even during the I-Corps meeting, the team had noticed that nanotechnology got a chilly reception from those in the know. Karl Handelsman, a venture capitalist and course instructor, quipped at one point: "The smallest thing about nanotechnology is the market."

From interviews the team learned that the word presents too many unknowns for consumers. "If you publish a paper with 'nano' in the title it gets a lot of buzz and attention," says Jordan Green, chief executive of AsclepiX. "But on the commercial side, they don't look at nano as a plus. It may even be a liability."

There were concerns about potential toxicity, and worries over how the Food and Drug Administration would evaluate a nanoparticle delivery system. Many were also worried about batch-to-batch variability in manufacturing.

AsclepiX is still young and flexible - the company has just three full-time employees and is still ordering basic equipment for its new laboratory in a renovated silverware factory. In response to the feedback, the company re-evaluated early animal tests of the peptide drug without a nanoparticle. The results were promising, says chief scientific officer Aleksander Popel. And Green says that the company is exploring ways of manufacturing the particle continuously, in the hope of alleviating concerns about batch-to-batch variability.

By the end of the nine-week I-Corps programme, others had changed strategy too. When participants reassembled for their final meeting in December, Affinity Therapeutics in Cleveland, Ohio, reported that interview number 82 had uncovered a fatal flaw in the company's product, an implanted device to repair blood vessels in patients on dialysis. Affinity's device is coated with a drug-releasing polymer designed to prevent smooth muscle cells from growing into the device - a process that gradually reduces the diameter of currently used products. "This will never work," a doctor told them, noting that muscle cells also grow into the natural blood vessel downstream of the device junction.

Then interviewee number 116, Timmy Lee at the University of Alabama at Birmingham, told them how to correct the problem by shifting the placement of the coating. In the meantime, the company learned more about regulation and billing practices. Before I-Corps, Affinity had been weighing up two possibilities: it could market the coated device or market the coating to be added to devices sold by other companies. The team learned that the first option could require approval from two different centres within the US Food and Drug Administration. Selling the coating alone was likely to involve only one centre, but would require the creation of a new hospital billing code, a process that can take years and cost millions of dollars. As a result, Affinity is mainly focusing on the coated device.

$\mathrm{BCN}$, the company developing drugs to protect normal tissue from radiation damage, had found a possible new application for its compounds. The doctors it interviewed kept returning to what had initially seemed an extraneous point: if the drug helped to prevent the formation of stiff tissue in the lung caused by radiation, perhaps it would also work against a spontaneous and devastating disease called idiopathic pulmonary fibrosis, which also causes lungs to stiffen.

The company initially disregarded the comments, but they kept coming up. Similarly, dermatologists had wondered whether the drug might battle the stiffening of skin that comes with ageing. $\mathrm{BCN}$ will expand its focus to include these other areas.

With the pressure of interview counts and coursework behind them, many of the teams expressed gratitude for the experience when they gathered for the final meeting. "I wasted millions on projects that were technically sexy and ultimately not commercially viable," said Mark Bates, a cardiologist and serial entrepreneur who was working with one of the teams. He turned to Blank. "I'm kind of pissed right now. Where were you 20 years ago?"

"I was pissing other people off," answered Blank, referring to his own failed companies. "I was losing \$35 million."

The NIH will be watching closely to see if its investment in I-Corps pays off. Michael Weingarten, head of the SBIR programme at the NCI, says that he will track the teams' success over the next five years - monitoring how many partnerships with major pharmaceutical or medical-device firms the companies form, and whether they receive funds from other investors. "We still have to show to NIH management that this is having a positive impact before we move to the next stage and get more companies involved," he said in October. For now, Weingarten says, the teams filled out surveys before and after the programme that indicate how much they think they have learned; $82 \%$ of participants said they would recommend the programme to others. $\mathrm{He}$ expects the NCI to decide whether or not to continue the programme within the next two months.

Meanwhile, Blank's method continues to spread. At the end of October, the US Department of Energy announced a project similar to I-Corps. Lipinski says that the Department of Defense is considering one as well. And Blank has been contacted by several university technology-transfer offices, asking for consultations on how they can use his methods to aid academic entrepreneurs. Imperial College in London, for example, has adopted a similar programme for start-ups based on synthetic biology.

Many of the NIH's inaugural teams say that they already have enough data to testify to the utility of I-Corps. Johnson's team from GigaGen has interviewed 256 people, 93 of them after I-Corps concluded. For the past few weeks, he has been pitching the company to venture capitalists, in the hope of raising more money for the firm. Venture capitalists can be a little snarky, he says, but he felt well prepared. "Normally they tend to just ask you questions until you just can't answer," he says. "But nobody's been able to ask me a question I haven't been able to answer yet."

Heidi Ledford writes for Nature from Cambridge, Massachusetts. 